Section Editor

Mitchell S.V. Elkind, MD, MS

\section{G. Fourcade, MD}

M. Chbicheb, MD

M. Durand-Roger, MD

D. Renard, MD

E. Nessere, MD

J. Rey, MD

Correspondence $\&$ reprin requests to Dr. Fourcade: gfblanchet@gmail.com

\title{
Teaching NeuroImages: \\ Cerebral and cervical venous air embolism
}

Figure 1 Facial and cerebral venous air embolism

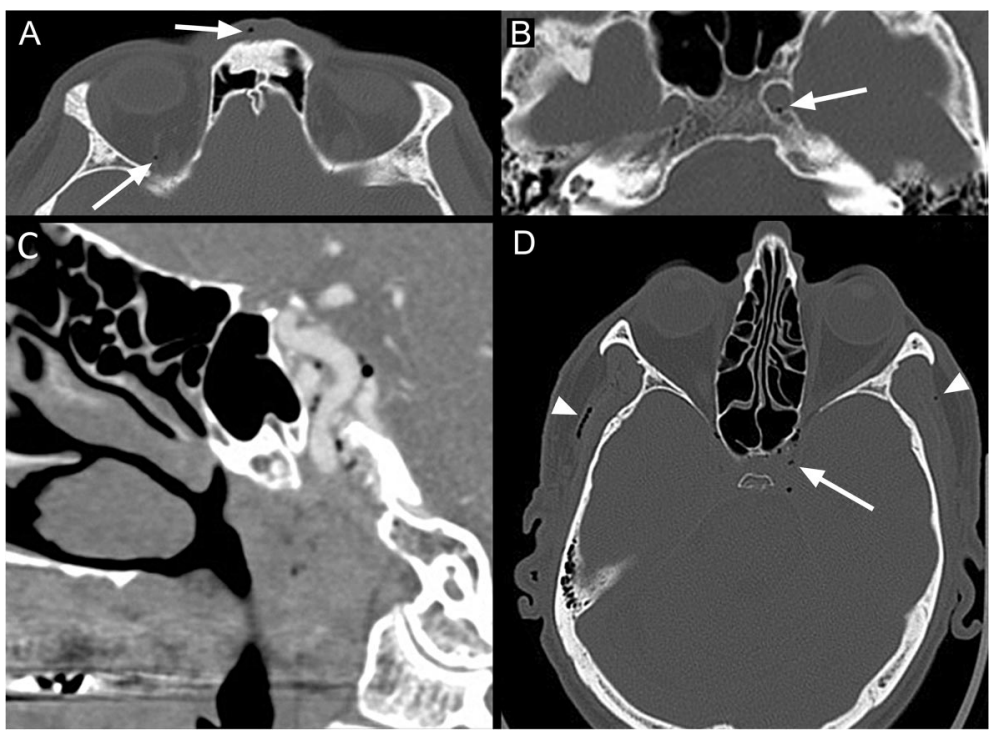

Axial (A, B, D) and sagittal (C) brain CT. Spots of low density suggest venous gas emboli in the right superior ophthalmic and angular veins (A), the left carotid canal (B), the bilateral cavernous sinus (arrows) (C, D), and the superficial temporal veins (arrowheads) (D).

A brain CT, performed because of subacute pain and weakness in the left arm of a 61-year-old man, revealed cerebral and faciocervical venous gas emboli (figures 1 and 2). A peripheral IV catheter had been placed 2 hours prior

\section{Figure 2 Cervical venous air embolism}

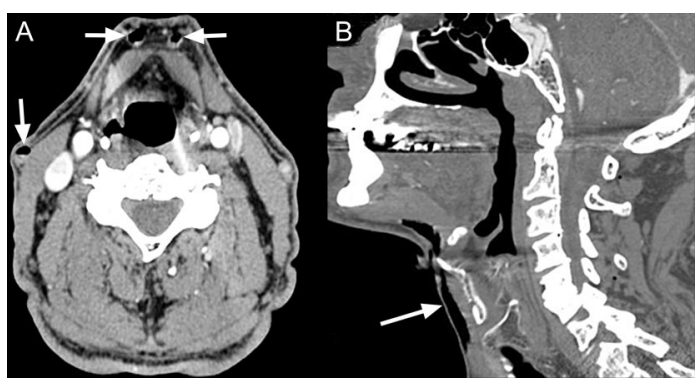

Axial (A) and sagittal (B) contrast-enhanced cranial CT. Areas of low density with hydro-aeric level in the bilateral anterior jugular veins $(A, B)$ and the right external jugular vein (A) (arrows) to CT without incident of disconnection. A second CT, performed 2 hours later, showed only persistent gas in the cavernous sinus. Twelve days later, CT was normal. Transthoracic echocardiogram was normal. The clinical course was consistent with neuralgic amyotrophy.

Asymptomatic cerebral venous air embolism has been described earlier after peripheral venous infusion. ${ }^{1}$ Jugular valve insufficiency might explain retrograde air passage through the internal jugular valves. ${ }^{2}$

\section{AUTHOR CONTRIBUTIONS}

Analysis of the data: G. Fourcade, M. Chbicheb, J. Rey, E. Nessere. Figure revision: M. Durand-Roger. Manuscript revision: D. Renard.

\section{REFERENCES}

1. Rubinstein D, Dangleis K, Damiano T. Venous air emboli identified on head and neck CT scans. J Comput Assist Tomogr 1996;20:559-562.

2. Nedelmann M, Pittermann P, Gast KK, Mueller-Forell W, Dieterich M. Involvement of jugular valve insufficiency in cerebral venous air embolism. J Neuroimaging 2007;17:258-260.

From the Departments of Neurology (G.F., M.C., J.R.), Emergency (M.D.-R.), and Radiology (E.N.), Hospital Center of Narbonne, Narbonne; and Department of Neurology (D.R.), CHU Nîmes, Nîmes, France.

Disclosure: The authors report no disclosures. 


\section{Neurology}

\section{Teaching NeuroImages: Cerebral and cervical venous air embolism}

G. Fourcade, M. Chbicheb, M. Durand-Roger, et al.

Neurology 2012;78;e94

DOI 10.1212/WNL.0b013e31824f8044

\section{This information is current as of April 9, 2012}

\section{Updated Information \&} Services

\section{References}

Subspecialty Collections

Permissions \& Licensing

Reprints including high resolution figures, can be found at: http://n.neurology.org/content/78/15/e94.full

This article cites 2 articles, 0 of which you can access for free at: http://n.neurology.org/content/78/15/e94.full\#ref-list-1

This article, along with others on similar topics, appears in the following collection(s):

\section{Embolism}

http://n.neurology.org/cgi/collection/embolism

Information about reproducing this article in parts (figures,tables) or in its entirety can be found online at:

http://www.neurology.org/about/about_the_journal\#permissions

Information about ordering reprints can be found online: http://n.neurology.org/subscribers/advertise

Neurology ${ }^{\circledR}$ is the official journal of the American Academy of Neurology. Published continuously since 1951, it is now a weekly with 48 issues per year. Copyright Copyright (? 2012 by AAN Enterprises, Inc.. All rights reserved. Print ISSN: 0028-3878. Online ISSN: 1526-632X.

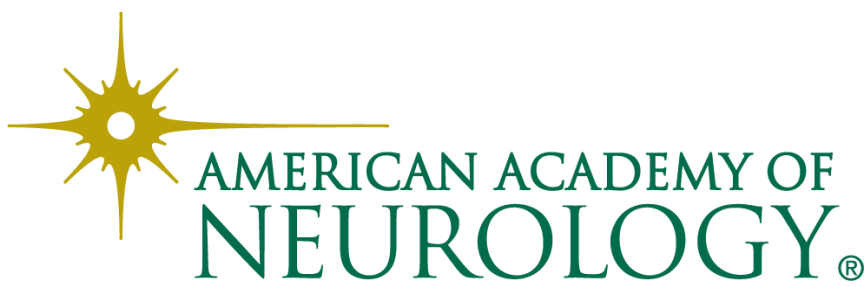

